\title{
Science Project-based Learning Integrated with Local Potential to Promote Student's Environmental Literacy Skills
}

\author{
Ellin Carlina ${ }^{1 *}$, Djukri $^{2}$ \\ ${ }^{1}$ Graduate Program of Science Education, Yogyakarta State University, Indonesia \\ ${ }^{2}$ Department of Biological Education, Yogyakarta State University, Indonesia \\ * Corresponding author email: ellin.carlina@gmail.com
}

Received: 25 May 2018 / Accepted: 28 June 2018 / Published: 3 July 2018

\begin{abstract}
ABSTRA C T
The learning process of science requires teaching which gives students the opportunity to be active in direct experience learning and thinking about the problems in real-life. However, science learning method that is widely used so far only conventionally, so it has not accommodated students in providing direct experience and solutions to real life problems. In order to realize the science learning that allows students to build their own understanding of real life problems, suitable learning model is needed and one of which is project-based learning. This research was conducted to know the effectiveness of science project-based learning which is integrated with natural potential of Baruppu' in Junior High School students' environmental literacy skills. Sample consisted of 50 students in grade VII of SMPN 1 Baruppu'. Quasi-experimental with Non-equivalent Control-Group Design was used to know the effectiveness of learning model in student's environmental literacy skills: cognitive skill and environmental affect components. The study design consists of two groups: 26 students of class VIIA as experimental group and 24 students of class VIIB as control group. Data collected consisted of scores that measured cognitive skill and scores from environmental affect survey. Data analysed utilizing an independent samples t-test to determine any differences in environmental literacy skills between experimental and control groups after treatment. The result showed that the science projectbased learning which is integrated with natural potential of Baruppu' was effective to promoted student's environmental literacy skills.
\end{abstract}

Keywords: environmental literacy, local potential, project-based learning.

\section{Introduction}

The nature on earth as our habitat provides enormous resources to meet the needs of human life. If these natural resources used properly, it will provide prosperity for human life. The natural potential of Baruppu' is related to its geographical condition which is a mountainous area with fertile soil and dominated by green forest. The specific natural potentials of Baruppu' are Upe (kind of purple taro), Arabica and Robusta coffee that have a very strong taste, Avocado, Sarambu (waterfall), historical caves of the Dutch colonial period and Puncak Baruppu' panorama. These great resources may potentially provide extra income for the local people. However, Baruppu's natural potential has not been utilized well and even tended to be damaged by human activities. Some of the factors causing underutilization of existing natural potentials are for example the lack of awareness and knowledge in managing the nature, also the laziness of the people due to the rapid development of technology.

Environmental awareness is one of the characters that needs to be built in the young generation. According to the law of National Education System Article 3, 2003, Character building as one of the objectives of national education is very important in producing a quality Indonesian generation. Environmental and societal issues related to the daily lives of students can improve their perception of the relevance of studying 
certain subject. In line with one of the learning objectives in Science class, environmental awareness will make the students participate actively in maintaining and preserving the environment and natural resources around them. With its great potential as learning resources, the nature itself could embed the environmental awareness as one of the responsibilities that must be owned by us humans that live depending on it. Environmental awareness is the main aspect needed to achieve environmental literacy skills.

Environmental literacy is an understanding of ecological systems, causal relationships between attitudes and human behavior towards the environment, and responsible to the environment [1]. Persons who are environmentally literate will have the sensitivity to the environmental issues, have the knowledge, skills, attitudes, motivation and commitment to work individually and collectively in finding solutions to current environmental problems [2]. All citizen, including students are responsible for Environmental issues, therefore ownership to the environment is important to be built in the school students' mentality through education. Environmental education in schools can be taught through specific subject (Environmental Education subject) or can be integrated into general subject such as science. One indicator in environmental education is knowing the level of persons' environmental literacy. A person with good environmental literacy has an awareness, knowledge, and sensitivity of natural balance and how this balance would be affected by people would be vaccinated [3]. The components of environmental literacy are: Ecological Knowledge, Environmental Affect, Cognitive Skills and Environmental Behavior [4]-[5]. The components of environmental literacy measured in this study are limited to the components of Environmental Affect and Cognitive Skills.

Integration of Baruppu's natural potential problems into science learning can facilitate students in building the environmental literacy skills. When students are exposed to environmental problems that occur around them, students will experience more meaningful learning. Research conducted by [6] indicated that integrated learning with real-world problems can develop students' environmental literacy skills. This study conducted in order to promote students' environmental literacy skills through project-based learning. Project-based learning is learning that can develop thinking skills to provide tangible solutions, team work, investigation and data collection skills, presentation skills and evaluation of learning process and outcomes [7]. Project-based learning also enables students to build their own knowledge through inquiry and can cooperatively research and create projects that reflect their knowledge [8]. Project-based learning blends traditional subject-matter goals and objectives with authentic learning environments which can enhanced understanding that develops through application and manipulation of knowledge within context [9]. To meet the need of $21^{\text {st }}$ century, students need to be equipped with knowledge and qualified skills. Knowledge and skills are reflected in individual performances either independently or collaboratively. Project-based learning is able to accommodate students to meet the demands of $21^{\text {st }}$ century skills by training students in cooperative work, analyzing real-world issues that occur around them, collecting and analyzing data, finding solutions to the problems and reflect on the learning process experienced. [10] and [11] emphasized the project-based learning on holistic-interdisciplinary learning activities, students-centered learning and integrated with real-world practices and issues. Project based learning syntax used in this study are as follow:

1) Diagnose the problem

2) Find and collect information that relevant to the problem

3) Analyze data to find information that can be a potential solution

4) Determine the best solution

5) Design the project

6) Execute the project

7) Presenting the project

8) Evaluation and reflection on project

Research conducted by [12] shows that project-based learning can improve students' understanding of the basic concepts of science and the application of scientific performance. This learning process was integrated with real problems that occur in the environment. Through this learning students gain the skills of collecting data and using the information obtained to solve real problems, as well as being able to high order thinking 
to accomplish the tasks assigned. Another research has been done by [13] found that project approach is more meaningful and diverse than the ordinary lessons, which most often include only writing and listening to the teacher's lectures. According to the students, the environmental issues and sustainability aspects in the project motivated them to study and became more environmentally orientated. Science project-based learning in this study was expected to build students' environmental literacy skills through the integration of environmental problems of utilization of Baruppu's natural potential.

\section{Materials and Method}

The empirical research was conducted with quasi-experimental method and the Nonequivalent ControlGroup Design [14]. The participants were 50 students of grade 7 of SMPN 1 Baruppu', 26 students from class $7 \mathrm{~A}$ as the experimental class and 24 students from class $7 \mathrm{~B}$ as the control class. The experimental class was treated with the project-based learning model integrated with Baruppu's natural potential, while the control class learned using traditional method. The students were divided into groups and they had to choose one of Baruppu's natural potentials according to their own interest. During the project, the students

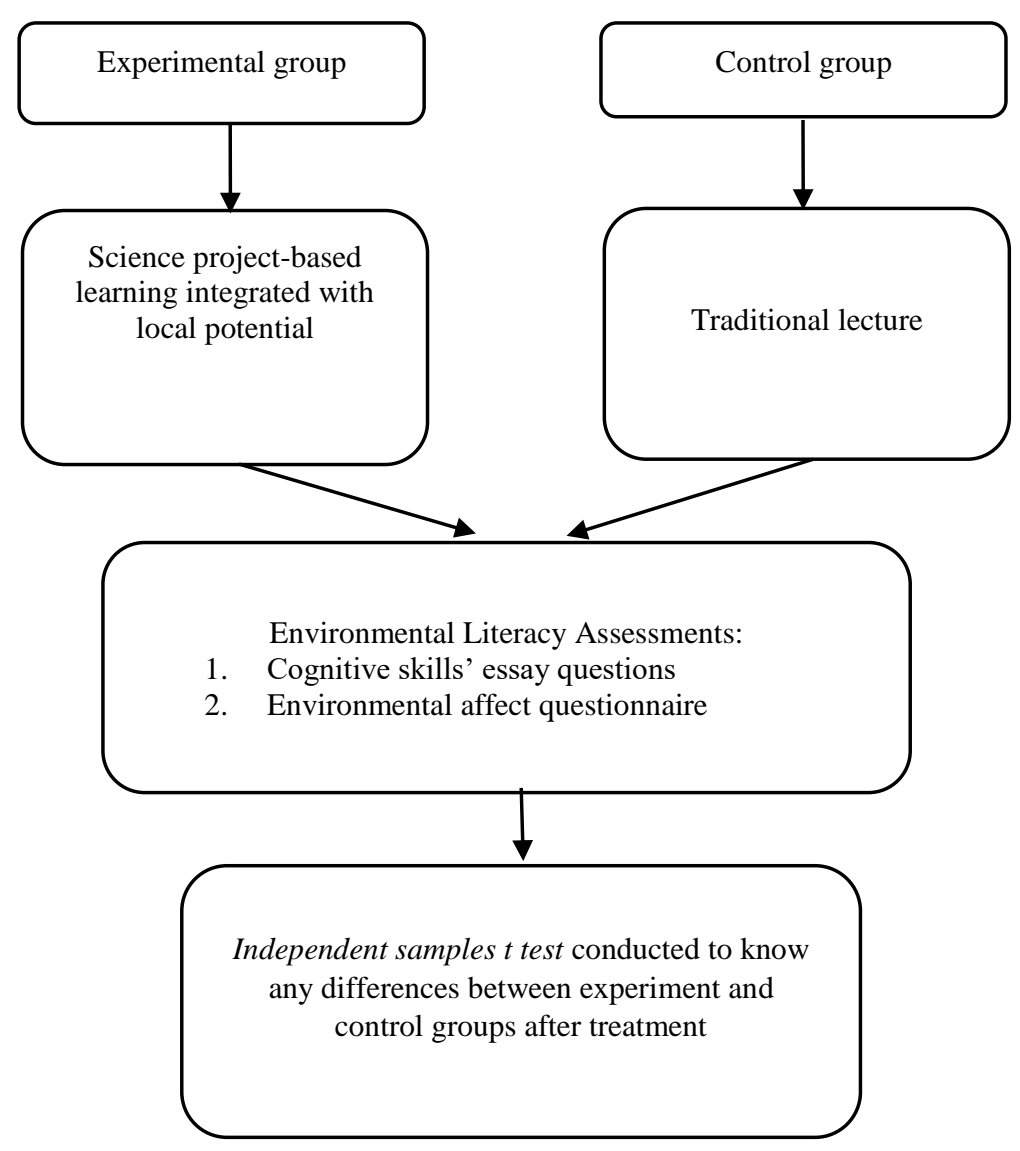

Figure 1: Research Design

were involved in diagnosing the problems, searching for information, discussing their findings in teams, make a poster, and presenting the results. At the end of the study, a test to measure students' environmental literacy skills was applied in both classes. The description of the research design is presented in Figure 1. Research instruments used are consisted of an essay questions of environmental literacy cognitive skill and environmental affection questionnaire adapted from the Middle School Environmental Literacy Survey / Instrument (MSELS / I) [4]. All instruments are integrated to local issue: The utilization of local natural potentials. Independent samples $t$-test was conducted to determine whether there is a significant difference between the experimental class and the control class after intervention. Independent samples $t$-test requires data to be normally distributed, therefore the normality test using Kolmogorov-Smirnov was performed both 
on the experimental class and control class. Hypothesis that will be tested using independent samples t-test is as follows:

$\mathrm{H}_{0}$ : There is no significant difference in the mean score of environmental literacy between the experimental class and the control class

$\mathrm{H}_{\mathrm{a}}$ : There is a significant difference in the mean score of environmental literacy between the experimental class and the control class

The level of significance is $\alpha=0.05 . \mathrm{H}_{0}$ rejected if the value of sig. 2 -tailed $<0.05$, otherwise $\mathrm{H}_{0}$ accepted if the significance value $\geq 0.05$.

\section{Results and Discussion}

One of the characteristics of learning science is giving students the opportunity to be active in direct learning experience and in thinking about the environmental problems around them. Based on the interview conducted with science teachers of SMPN 1 Baruppu', the learning process in Science class has not facilitated students to be active in experiencing direct contact of the real-world problems yet. The result of literatures study [8] [9] and previous researches [12] [15] indicated that learning models that can provide opportunities for students to be actively involved in direct experience of problems is the project-based learning model. The experimental class was given treatment with project-based learning model integrated natural potential of Baruppu', while the learning method of control class was a traditional lecture. In the experimental class, the students were divided into 5 groups. They were assigned to make posters and present it later on. The poster contains solutions for the utilization of Baruppu's natural resources that potentially possible to be developed. Group 1 discussed the potential of Upe, group 2 discussed the potential of Avocado, group 3 discussed the panorama of Puncak Baruppu' as a potential tourist attraction; group 4 discussed the potential of Sarambu Marendeng waterfall and group 5 discussed the potential of Baruppu's Coffee. The learning steps in the lesson plan are based on project-based learning syntax and adjusted to the learning steps in Indonesian curriculum 2013 (Observing, Asking, Exploring, Associating and Communicating). Lesson plans were made for 4 meetings with time allocations of 2 X 40 minutes. At the first meeting, an observation was conducted around the school yard. Lesson began by described the environmental concepts based on illustration in students' worksheet and identified the biotic and abiotic components. Activities continued outside the classroom to observed ecosystems around the school and the results data recorded in table. The second to fourth meetings discussed about the project of utilizing the natural potential of Baruppu'. Project began with problems diagnosis, identification and collecting information, data analysis to find potential solutions, determine appropriate solution to problem, and design the poster. The next step was the execution of the plans, where students made the poster according to the natural potential of Baruppu' which has been selected by each group. The last step was the project presentation and evaluation activities. At this step each groups presented their poster and at the end of the lesson wrote an evaluation and reflection on the learning process. An environmental literacy test was given after the project-based learning model applied. The same test was also applied to the control class to determine whether there is a difference between the control and experimental classes after intervention. The results of cognitive skills' test and environment affects' questionnaire are shown in Figure 2.

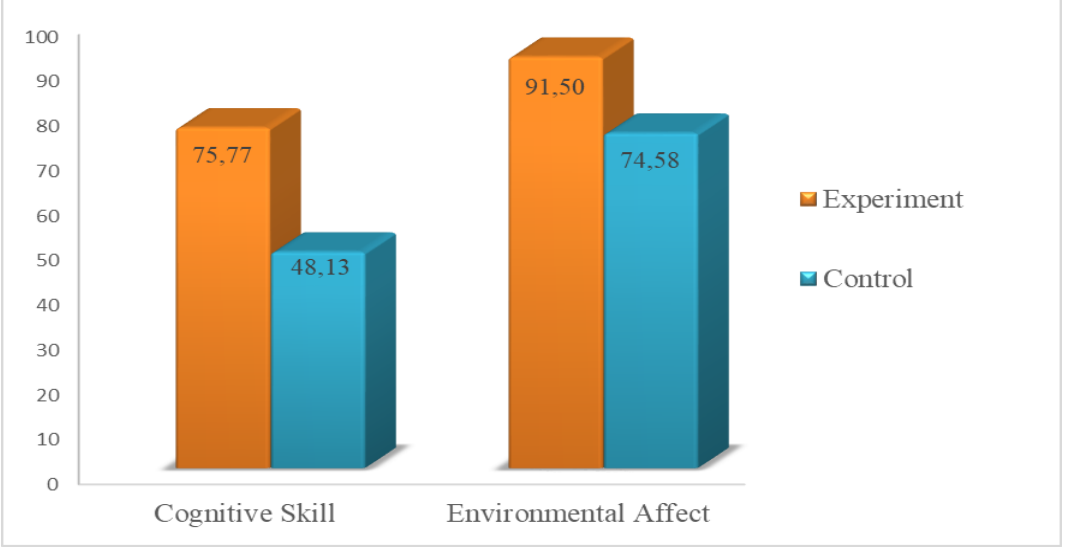

Figure 2: Result of Environmental Literacy Skills 
Figure 2 shows the average score of cognitive skill in experimental class is 75.77 and the average score of cognitive skill in control class is 48.13. As for the environmental affects' component, the average score obtained was 91.50 in experimental class and 74.58 in control class. This significant difference in scores gain proved that the class with science project-based learning integrated in the topic Baruppu's natural potential had greater environmental literacy skills than untreated class.

Table 1: Normality Test Result

\begin{tabular}{|c|c|c|c|c|c|}
\hline No & Classes & & Components & $\mathbf{p}$ & conclusion \\
\hline \multirow{2}{*}{1} & \multirow{2}{*}{ Experiment } & a) & Cognitive Skill & 0,162 & Normal \\
\hline & & b) & Environmental Affect & 0,339 & Normal \\
\hline \multirow{2}{*}{2} & \multirow{2}{*}{ Control } & a) & Cognitive Skill & 0,365 & Normal \\
\hline & & b) & Environmental Affect & 0,324 & Normal \\
\hline
\end{tabular}

Normality test was performed as a prerequisite for testing the research hypothesis. The result of KolmogorovSmimov normality test using SPSS program presented in table 1 shows that $\mathrm{p}$ value $>0,05$. Thus, this result means that the data used comes from normally distributed population.

Data analysis conducted to determine whether there is a significant difference between the experimental class and control class after intervention was independent samples t-test using SPSS program. The test results are presented in Table 2. The significance value of 2 -tailed test results shows the number 0.000 $<0.05$. Based on the significance value of the test results, $\mathrm{H}_{0}$ is rejected and $\mathrm{H}_{\mathrm{a}}$ is accepted. The test results show that there were significant differences in the students' environmental literacy skills between the experimental class and the control class.

Table 2: Result of Independent Samples t-test

\begin{tabular}{|l|l|c|c|c|}
\hline Components & & $\mathbf{t}$ & $\mathbf{d f}$ & Sig.2-tailed \\
\hline Cognitive skill & Equal variances assumed & 21,482 & 48 & 0,000 \\
\cline { 2 - 5 } & Equal variances not assumed & 21,595 & 47,893 & 0,000 \\
\hline Environmental affect & Equal variances assumed & 20,225 & 46 & 0,000 \\
\cline { 2 - 5 } & Equal variances not assumed & 21,905 & 26,905 & 0,000 \\
\hline
\end{tabular}

The achievement of student's environmental literacy cannot be separated from the integration of natural potential utilization problems into project-based learning. The result of cognitive skill assessment after intervention, reveals that learners are able to identify, analyze and design solutions to the problems of natural potential utilization. During project-based learning process, learners are brought into real-world problems and trained to link learning experiences to the environment they live. Learning by providing direct experience of real-world problems is one of the key to develop students' environmental literacy. The instrument of cognitive skills' essay was preceded by a text reading about the natural potential of Baruppu'. From the text, students identified problems, suggested potential strategies for solutions and determine the right solution to the problem. From the essay questions students found it hard to understand some terms used in the questions, such as 'identify' and 'solution', so the teacher must explain the meaning of the words in simpler way. The lack of understanding some terms in the essay questions though those are Indonesian standard language was because of the students' unfamiliarity with those terms, and also the main language used in daily in the society in not the standard Indonesian language but traditional local language.

The questionnaire indicated that project-based learning makes the students becoming more aware to the environmental issues around them. This can be seen from their responses where most of them knew what natural potentials they have in their area. They also knew the consequences they are going to face if the 
environment is not properly maintained, and no commitment made to preserve the environment. The increase of students' environmental awareness can also be seen through posters the student made as learning products. The strategies described in the poster are still very simple and general, because students are not yet accustomed to project learning and have difficulty in gathering information. This constraint is one of the weaknesses of project learning by [16] that students who are not accustomed to collect information will have difficulty. Integrating the problems of utilization of natural potency into the learning made learners more interested and sensitive to environmental problems as well as to develop the skills of environmental literacy. This is supported by the results of research [6] who conclude learning that integrates real problems that occur in the environment can develop students' literacy skills related to environment itself.

\section{Conclusion}

Based on the findings and the results of the analysis, this study concludes that project-based learning integrated into Baruppu's natural potential topic was effective in building the environmental literacy of junior high school students in grade 7 . The analysis results reveal that there is a significant difference between the classes that were taught by project-based learning and the classes that were not taught by project-based learning. For further research it is advisable to add other environmental literacy components, such as ecological knowledge components and behavioral components, so that all components of environmental literacy are included.

\section{How to Cite this Article}

Carlina, E., \& Djukri. (2018). Science Project-based Learning Integrated with Local Potential to Promote Student's Environmental Literacy Skills. Advanced Journal of Social Science, 4(1), 1-7. doi: 10.21467/ajss.4.1.1-7

\section{References}

[1] Maknum, Djohar. (2011). Praktikum proyek ekologi berbasis kondisi ekobiologis lokal dalam meningkatkan literasi lingkungan dan tindakan konservasi mahasiswa. Holistik, 12(02). Retrieved from http://www.syekhnurjati.ac.id/jurnal/index.php/holistik/article/view/85/87

[2] Varisly, T. (2009). Evaluating eighth grade students' environmental literacy: the role of socio-demographic variables. Thesis, Middle East Technical University. Retrieved from https://etd.lib.metu.edu.tr/upload/12610808/index.pdf

[3] Özgürler, S. and Cansaran, A. (2014). Graduate students, study of environmental literacy and sustainable development. International Electronic Journal of Environmental Education, 4(2), 71-83. Retrieved from https://files.eric.ed.gov/fulltext/EJ1060538.pdf

[4] McBeth, B., Hungerford, H., Marcinkowski, T., Volk, T. \& Cifranick, K. (2011). National Environmental Literacy Assessment, phase two: Measuring the effectiveness of North American environmental education programs with respect to the parameters of environmental literacy. Final Research Report. Retrieved from http://www.oesd.noaa.gov/outreach/reports/NELA_Phase_Two_Report_020711.pdf

[5] North Califonia State University (NCSU). (2012). North California environmental literacy plan. Retrieved from http://www.eenorthcarolina.org/educatorsliteracy-plan.html

[6] Mukhyati \& Sriyati. (2015). Bahan ajar perubahan lingkungan berbasis realitas lokal dan literasi lingkungan. Article presented in Seminar Nasional XII Pendidikan Biologi FKIP, Universitas Negeri Surakarta. Retrieved from https://media.neliti.com/media/publications/175255-ID-none.pdf

[7] Kubiatko, M. \& Vaculova, I. (2011). Project-based learning: characteristic and the experiences with application in the science subjects. Energy Education Science and Technology Part B: Social and Educational Studies, 3(1), 65-74. Retrieved

from http://www.kubiatko.eu/clanky_pdf/project_based_learning_\%20characteristic_and_the_experiences_with_applicati on_in_the_science_subjects.pdf

[8] Bell, Stephanie. (2010). Project-based learning for the 21st century: Skills for the future. The Clearing House, 83, 3943. Retrieved from http://www.jstor.org/stable/20697896

[9] Eskrootchi, R., \& Oskrochi, G. R. (2010). A study of the efficacy of project-based learning integrated with computerbased simulation-STELLA. Educational Technology \& Society, 13 (1), 236-245. Retrieved from http://www.jstor.org/stable/jeductechsoci.13.1.236 
Carlina et al., Adv. J Social Sci.; Vol. 4 Issue 1, pp: 1-7, 2019

[10] Rais. (2010). Project-based learning: Inovasi pembelajaran yang berorientasi soft skills. Article presented in Seminar Nasional Pendidikan Teknologi dan Kejuruan Fakultas Teknik, Universitas Negeri Surabaya. http://digilib.unm.ac.id/files/disk1/1/universitas\%20negeri\%20makassar-digilib-unm-drmuhraiss-20-1-makalah-a.pdf

[11] Sadeghil, H., Biniaz, M. \& Soleimani, H. (2016). The impact of project-based language learning on Iranian efl learners' comparison/contrast paragraph writing skills. International Journal of Asian Social Science, 6 (9), 510-524. Retrieved from http://www.aessweb.com/html/3413

[12] Dresher, P. A. (2013). The effects of implementing project-based learning in the middle school science classroom. Thesis, Montana State University, Bozeman, Montana. Retrieved from https://scholarworks.montana.edu/xmlui/handle/1/2777

[13] Juntenen, M. \& Aksela, M. (2013). Life-cycle thinking in inquiry-based sustainability education - effects on students' attitudes towards chemistry and environmental literacy. Center for Educational Policy Studies Journal, 3(2), 157-180. Retrieved from https://ojs.cepsj.si/index.php/cepsj/article/view/244/157

[14] Mitchell, M. L. \& Jolley, J. M. (2007). Research design explained sixth edition. USA: Thomson Higher Education.

[15] Chiang, C. L. \& Lee, H. (2016). The effect of project-based learning on learning motivation and problem solving ability of vocational high school students. International Journal of Information and Education Technology, 6 (9), 709-712. Retrieved from http://www.ijiet.org/show-76-881-1.html

[16] Sumarni, W. (2015). The strengths and weaknesses of the implementation of project based learning: A review. International Journal of Science and Research (IJSR), 4 (3), 478-484. Retrieved from https://www.ijsr.net/archive/v4i3/SUB152023.pdf

Publish your research article in AIJR journals-

$\checkmark$ Online Submission and Tracking

$\checkmark$ Peer-Reviewed

$\checkmark$ Rapid decision

$\checkmark$ Immediate Publication after acceptance

$\checkmark$ Articles freely available online

$\checkmark$ Retain full copyright of your article.

Submit your article at journals.aijr.in
Publish your books with AIJR publisher-

$\checkmark$ Publish with ISBN and DOI.

$\checkmark$ Publish Thesis/Dissertation as Monograph.

$\checkmark$ Publish Book Monograph.

$\checkmark$ Publish Edited Volume/ Book.

$\checkmark$ Publish Conference Proceedings

$\checkmark$ Retain full copyright of your books.

Submit your manuscript at books.aijr.org 